\title{
A Pd-Bi Dual-Cocatalyst-Loaded Gallium Oxide Photocatalyst for Selective and Stable Nonoxidative Coupling of Methane
}

\footnotetext{
Surya Pratap Singh, ${ }^{a}$ Akira Yamamoto, ${ }^{\mathrm{a}, \mathrm{b}}$ Eri Fudo, ${ }^{\mathrm{c}}$ Atsuhiro Tanaka, ${ }^{\mathrm{d}, \mathrm{e}}$ Hiroshi Kominami, ${ }^{d}$ and Hisao Yoshida ${ }^{a, b, *}$

a Graduate School of Human and Environmental Studies, Kyoto University, Kyoto 606-8501, Japan

${ }^{b}$ Elements Strategy Initiative for Catalysts and Batteries (ESICB), Kyoto University, Kyoto 615-8245, Japan

${ }^{c}$ Molecular and Material Engineering, Interdisciplinary Graduate School of Science and Engineering, Kindai University, Higashiosaka, Osaka 577-8502, Japan

${ }^{d}$ Department of Applied Chemistry, Faculty of Science and Engineering, Kindai University, Higashiosaka, Osaka 577-8502, Japan

e Precursory Research for Embryonic Science and Technology (PRESTO), Japan Science and Technology Agency (JST), Kawaguchi 332-0012, Japan

*Corresponding author: yoshida.hisao.2a@kyoto-u.ac.jp
} 


\section{Contents}

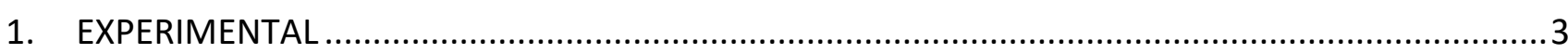

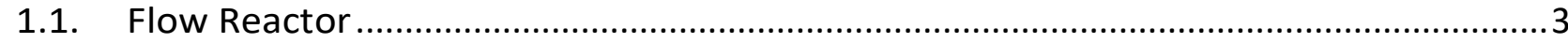

1.2. Calculation of Methane Conversion, Selectivity and Apparent Quantum Efficiency ...4

1.3. Composition of the various $\mathrm{M}_{1}-\mathrm{M}_{2} / \mathrm{MO}$ Samples .................................................. 5

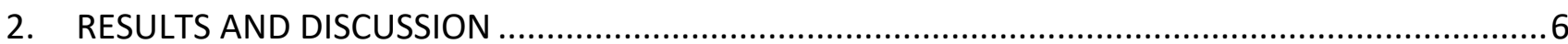

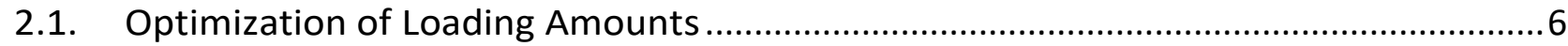

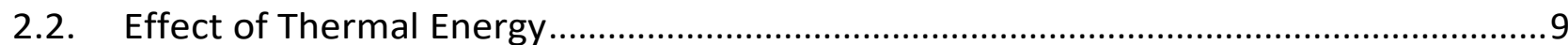

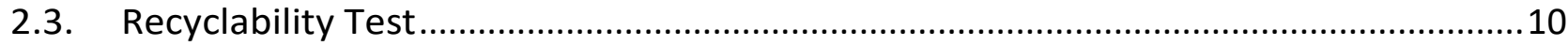

2.4. Color Change in $\mathrm{TiO}_{2}$ after the Reaction .................................................................11

2.5. BET Specific Surface Areas of the Samples .............................................................11

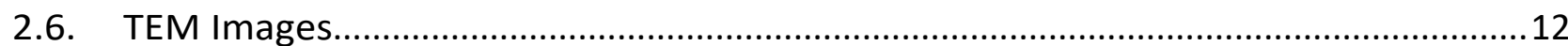

2.7. Photographs of the Irradiated and Non-irradiated Side of the Sample Cell ...............13

2.8. Reaction Test over the Reduced $\mathrm{Pd}-\mathrm{Bi} / \mathrm{Ga}_{2} \mathrm{O}_{3}$ Sample ...............................................14

2.9. Reaction Test over the $\mathrm{Pd}-\mathrm{Bi} / \mathrm{Ga}_{2} \mathrm{O}_{3}$ Sample with a Filter $(\lambda \geq 330 \mathrm{~nm}) \ldots \ldots \ldots \ldots \ldots \ldots . . . . . . .15$

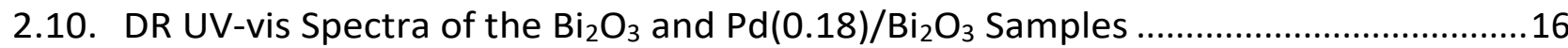

2.11. Reaction Test over the Bare $\mathrm{Bi}_{2} \mathrm{O}_{3}$ Sample and the $\mathrm{Pd} / \mathrm{Bi}_{2} \mathrm{O}_{3}$ Sample $\ldots \ldots \ldots \ldots \ldots \ldots \ldots \ldots . . . . . . . . .17$

2.12. Effect of Irradiation Area on the Photocatalytic Activity ..............................................18

2.13. Integration Manner of $\mathrm{Pd} / \mathrm{Ga}_{2} \mathrm{O}_{3}$ and $\mathrm{Bi} / \mathrm{Ga}_{2} \mathrm{O}_{3}$ Samples .......................................19

2.14. Time Course of the NOCM over the LCM Sample.........................................................19

2.15. Relationship between the Production Rates and the $R$ value ...................................20

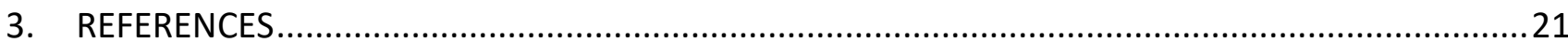




\section{EXPERIMENTAL}

\subsection{Flow Reactor}

The flow reactor employed in the photocatalytic activity test is shown in Fig. S1 ${ }^{1-5}$ and the photograph of the sample cell is shown in the inset of Fig. S1.

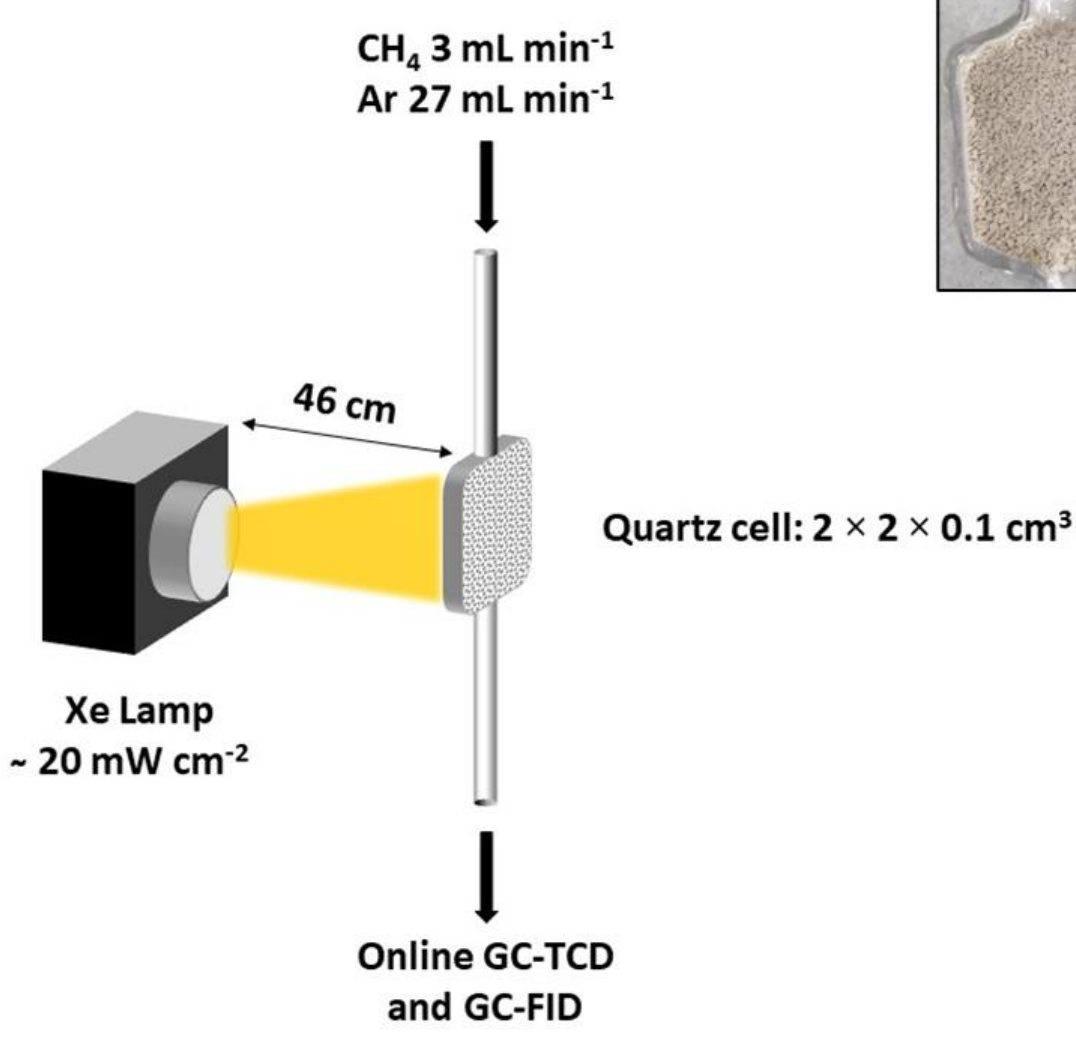

Fig. S1. The schematic diagram of the experimental set-up used in the photocatalytic reaction test of the NOCM. Inset: The photograph of the sample cell filled with the granules of the $\mathrm{Pd}(0.18)-\mathrm{Bi}(0.05) / \mathrm{Ga}_{2} \mathrm{O}_{3}$ photocatalyst. The size of the sample cell was $2 \mathrm{~cm} \times 2 \mathrm{~cm} \times$ $0.1 \mathrm{~cm}$. The distance between the lamp and the reactor was nearly $46 \mathrm{~cm}$ and the light intensity measured by a UV radiometer in the range of 220-300 $\mathrm{nm}$ (the highest sensitivity was at $254 \mathrm{~nm}$ ) was ca. $20 \mathrm{~mW} \mathrm{~cm}{ }^{-2}$. The photograph of the sample cell was taken by S.P. Singh. 


\subsection{Calculation of Methane Conversion, Selectivity and Apparent Quantum Efficiency}

The methane conversion (\%) was defined as the ratio of moles of methane consumed in the reaction to the total moles of methane introduced.

$$
\text { Methane conversion }(\%)=\frac{\text { Moles of methane consumed }}{\text { Moles of methane introduced }} \times 100
$$

The reaction selectivity (\%) was defined as the ratio of the consumed methane amount in the NOCM to the total consumed methane amount in the NOCM and the MD reactions.

$$
\text { Selectivity }(\%)=\frac{\text { Consumed methane in the NOCM }}{\text { Consumed methane in the }(\text { NOCM }+M D)} \times 100
$$

where the amount of the consumed methane was estimated from the obtained gaseous products, ethane and hydrogen according to the equations 1 and 2 in the main text.

The apparent quantum efficiency (AQE) was calculated by the following equation as the ratio of the number of consumed electrons for the reaction and the number of incident photons. ${ }^{6}$

$$
A Q E(\%)=\frac{r \times n \times N}{(I \times A) /(h c / \lambda)} \times 100
$$

where $r=$ production rate of $\mathrm{H}_{2}$ (in $\mathrm{mol} \mathrm{s}^{-1}$ ), $n=$ number of electrons consumed for the production of $\mathrm{H}_{2}(n=2), N=$ Avogadro constant (in mol $\left.{ }^{-1}\right), I=$ Intensity of the incident light measured by a UV photometer in the wavelength range of $220-300 \mathrm{~nm}$ (in $\mathrm{W} \mathrm{cm}^{-2}$ ), $A=$ Area of the reactor (in $\mathrm{cm}^{2}$ ), $h=$ Planck's constant (in J s), $c=$ speed of light (in $\mathrm{m} \mathrm{s}^{-1}$ ), $\lambda=$ wavelength of incident light (in $\mathrm{m}$ ). The wavelength range is almost the same as the absorption range $(200-300 \mathrm{~nm})$ of the $\mathrm{Ga}_{2} \mathrm{O}_{3}$ photocatalysts as shown in Fig. 7. 


\subsection{Composition of the various $\mathrm{M}_{1}-\mathrm{M}_{2} / \mathrm{MO}$ Samples}

The compositions of the $\mathrm{Pd} / \mathrm{Ga}_{2} \mathrm{O}_{3}$ sample and various $\mathrm{M}_{1}-\mathrm{M}_{2} / \mathrm{Ga}_{2} \mathrm{O}_{3}$ samples in wt. $\%$ are listed in the Table S1 as references. The loading amount of each element was $0.18 \mathrm{~mol} \%$.

Table S1. The compositions of $\mathrm{Pd} / \mathrm{Ga}_{2} \mathrm{O}_{3}$ and various dual-cocatalysts loaded $\mathrm{Ga}_{2} \mathrm{O}_{3}$ samples

\begin{tabular}{|c|c|c|c|c|c|c|c|}
\hline \multirow{2}{*}{$\begin{array}{c}\text { Dual- } \\
\text { cocatalyst } \\
(1: 1 / \mathrm{mol})^{*}\end{array}$} & \multicolumn{3}{|c|}{$\begin{array}{c}\text { Cocatalyst Composition } \\
\text { (wt. \%) }\end{array}$} & \multirow{2}{*}{$\begin{array}{c}\text { Dual- } \\
\text { cocatalyst } \\
(1: 1 / \mathrm{mol})^{*}\end{array}$} & \multicolumn{3}{|c|}{$\begin{array}{c}\text { Cocatalyst Composition } \\
\text { (wt. \%) }\end{array}$} \\
\hline & $\mathrm{M}_{1}$ & $\mathrm{M}_{2}$ & Total & & $\mathrm{M}_{1}$ & $\mathrm{M}_{2}$ & Total \\
\hline$P d-P$ & 0.1 & 0.03 & 0.13 & $\mathrm{Pd}-\mathrm{Sn}$ & 0.1 & 0.11 & 0.21 \\
\hline $\mathrm{Pd}-\mathrm{Mn}$ & 0.1 & 0.05 & 0.15 & $\mathrm{Pd}-\mathrm{Sb}$ & 0.1 & 0.11 & 0.21 \\
\hline $\mathrm{Pd}-\mathrm{Fe}$ & 0.1 & 0.05 & 0.15 & $\mathrm{Pd}-\mathrm{Cs}$ & 0.1 & 0.12 & 0.22 \\
\hline $\mathrm{Pd}-\mathrm{Co}$ & 0.1 & 0.06 & 0.16 & $\mathrm{Pd}-\mathrm{Sm}$ & 0.1 & 0.14 & 0.24 \\
\hline $\mathrm{Pd}-\mathrm{Ni}$ & 0.1 & 0.06 & 0.16 & Pd-Ir & 0.1 & 0.18 & 0.28 \\
\hline $\mathrm{Pd}-\mathrm{Cu}$ & 0.1 & 0.06 & 0.16 & $\mathrm{Pd}-\mathrm{Pt}$ & 0.1 & 0.18 & 0.28 \\
\hline $\mathrm{Pd}-\mathrm{Zn}$ & 0.1 & 0.06 & 0.16 & $\mathrm{Pd}-\mathrm{Au}$ & 0.1 & 0.19 & 0.29 \\
\hline $\mathrm{Pd}-\mathrm{Rh}$ & 0.1 & 0.1 & 0.2 & $\mathrm{Pd}-\mathrm{Pb}$ & 0.1 & 0.19 & 0.29 \\
\hline $\mathrm{Pd}$ & 0.1 & & 0.1 & $\mathrm{Pd}-\mathrm{Bi}$ & 0.1 & 0.20 & 0.30 \\
\hline $\mathrm{Pd}-\mathrm{Ag}$ & 0.1 & 0.1 & 0.2 & Pt-Bi & 0.19 & 0.20 & 0.39 \\
\hline
\end{tabular}

*The loading amount of each cocatalyst element was $0.18 \mathrm{~mol} \%$.

The compositions of other $\mathrm{Pd}(0.18)-\mathrm{Bi}(0.18) / \mathrm{MO}(\mathrm{MO}=$ metal oxide $)$ samples in wt. \% are listed in the Table S2 as references. The loading amount of each element was $0.18 \mathrm{~mol} \%$.

Table S2. The compositions of various Pd-Bi loaded metal oxide samples

\begin{tabular}{cccc}
\hline Pd-Bi/Catalyst & \multicolumn{3}{c}{ Cocatalyst Composition (wt. \%) } \\
\cline { 2 - 4 }$\left(1: 1 / \mathrm{mol}^{*}\right.$ & $\mathrm{Pd}$ & $\mathrm{Bi}$ & Total \\
\hline $\mathrm{Pd}-\mathrm{Bi} / \mathrm{Ga}_{2} \mathrm{O}_{3}$ & 0.10 & 0.20 & 0.30 \\
$\mathrm{Pd}-\mathrm{Bi} / \mathrm{CeO}_{2}$ & 0.11 & 0.22 & 0.33 \\
$\mathrm{Pd}-\mathrm{Bi} / \mathrm{ZnO}$ & 0.24 & 0.46 & 0.70 \\
$\mathrm{Pd}-\mathrm{Bi} / \mathrm{TiO}_{2}$ & 0.24 & 0.47 & 0.71 \\
$\mathrm{Pd}-\mathrm{Bi} / \mathrm{Al}_{2} \mathrm{O}_{3}$ & 0.19 & 0.37 & 0.56 \\
$\mathrm{Pd}-\mathrm{Bi} / \mathrm{SiO}_{2}$ & 0.32 & 0.63 & 0.95 \\
\hline
\end{tabular}

* The loading amount of each cocatalyst element was 0.18 mol\%. 


\section{RESULTS AND DISCUSSION}

\subsection{Optimization of Loading Amounts}

The loading amount of both $\mathrm{Pd}, \mathrm{Bi}$ and the total loading amount of $\mathrm{Pd}-\mathrm{Bi}$ were optimized. Fig. S2 shows the optimization of loading amount of $\mathrm{Pd}$ cocatalyst in the $\mathrm{Pd}(x)-\mathrm{Bi}(0.18) / \mathrm{Ga}_{2} \mathrm{O}_{3}$ samples.

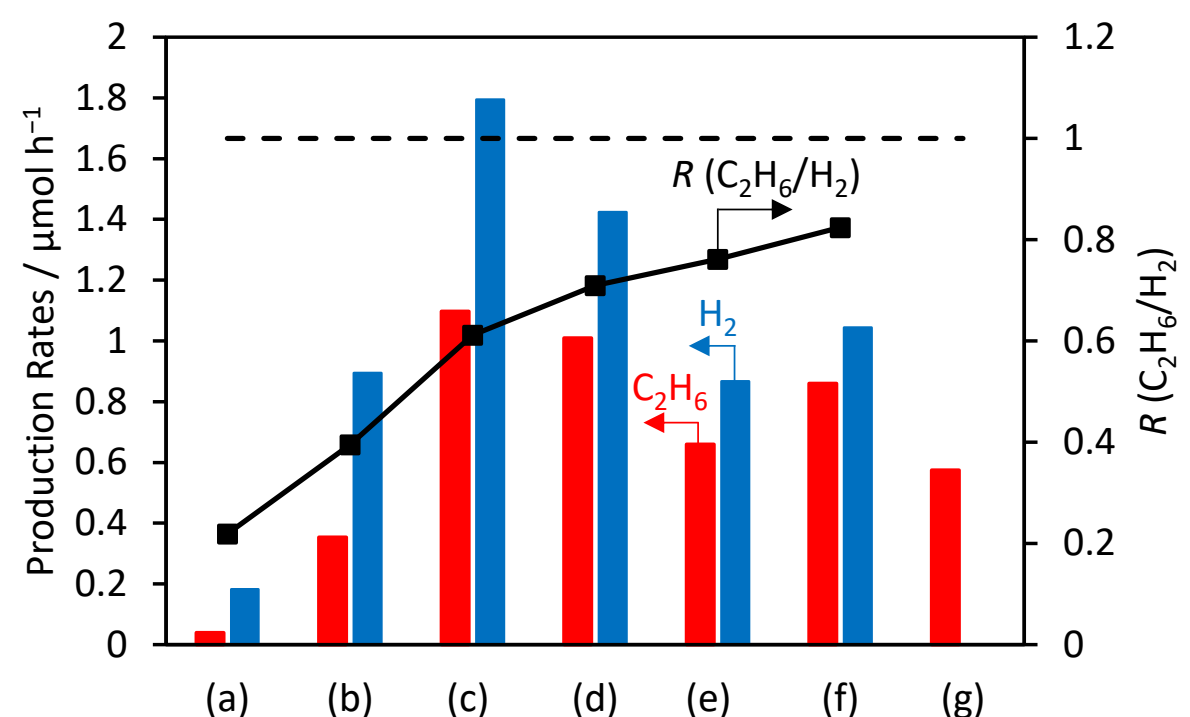

Fig. S2. Results of the NOCM reaction tests over the samples, (a) bare $\mathrm{Ga}_{2} \mathrm{O}_{3}$, (b) $\mathrm{Pd}(0.18) / \mathrm{Ga}_{2} \mathrm{O}_{3}$, (c) $\mathrm{Pd}(0.05)-\mathrm{Bi}(0.18) / \mathrm{Ga}_{2} \mathrm{O}_{3}$, (d) $\mathrm{Pd}(0.1)-\mathrm{Bi}(0.18) / \mathrm{Ga}_{2} \mathrm{O}_{3}$, (e) $\mathrm{Pd}(0.18)-\mathrm{Bi}(0.18) / \mathrm{Ga}_{2} \mathrm{O}_{3}$, (f) $\mathrm{Pd}(0.3)-$ $\mathrm{Bi}(0.18) / \mathrm{Ga}_{2} \mathrm{O}_{3}$, and $(\mathrm{g}) \mathrm{Pd}(0.4)-\mathrm{Bi}(0.18) / \mathrm{Ga}_{2} \mathrm{O}_{3}$. Red and blue solid bars represent the production rates of ethane and hydrogen, respectively. Black solid line with markers represents the ratio of the production rates of ethane and hydrogen, $R\left(\mathrm{C}_{2} \mathrm{H}_{6} / \mathrm{H}_{2}\right)$, while the black dashed line represents the ideal ratio $R\left(\mathrm{C}_{2} \mathrm{H}_{6} / \mathrm{H}_{2}\right)=1$. Reaction conditions were the same as those described in the footnote $a$ of Table 1. 
Fig. S3 shows the optimization of loading amount of $\mathrm{Bi}$ cocatalyst in the $\mathrm{Pd}(0.18)$ $\mathrm{Bi}(y) / \mathrm{Ga}_{2} \mathrm{O}_{3}$ samples.

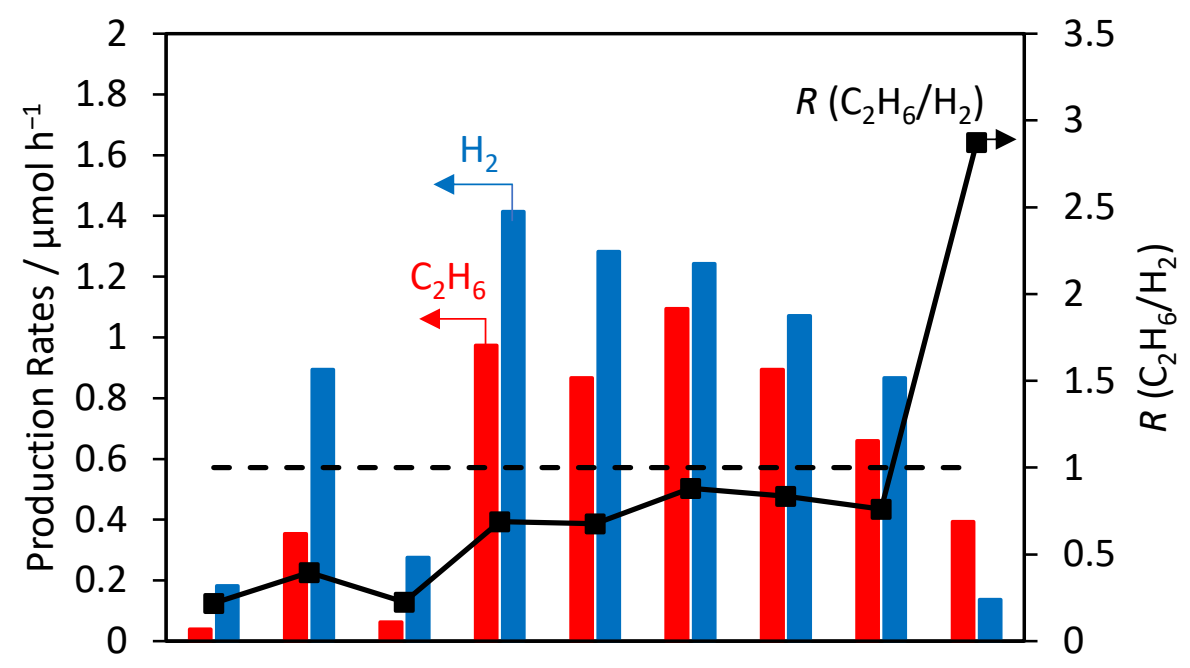

$\begin{array}{llllllllll}\text { (a) } & \text { (b) } & \text { (c) } & \text { (d) } & \text { (e) } & \text { (f) } & \text { (g) } & \text { (h) } & \text { (i) }\end{array}$

Fig. S3. Results of the NOCM reaction tests over the samples, (a) bare $\mathrm{Ga}_{2} \mathrm{O}_{3}$, (b) $\mathrm{Pd}(0.18) / \mathrm{Ga}_{2} \mathrm{O}_{3}$, (c) $\mathrm{Bi}(0.18) / \mathrm{Ga}_{2} \mathrm{O}_{3}$, (d) $\mathrm{Pd}(0.18)-\mathrm{Bi}(0.02) / \mathrm{Ga}_{2} \mathrm{O}_{3}$, (e) $\mathrm{Pd}(0.18)-\mathrm{Bi}(0.035) / \mathrm{Ga}_{2} \mathrm{O}_{3}$, (f) $\mathrm{Pd}(0.18)-$ $\mathrm{Bi}(0.05) / \mathrm{Ga}_{2} \mathrm{O}_{3}$, (g) $\mathrm{Pd}(0.18)-\mathrm{Bi}(0.1) / \mathrm{Ga}_{2} \mathrm{O}_{3}$, (h) $\mathrm{Pd}(0.18)-\mathrm{Bi}(0.18) / \mathrm{Ga}_{2} \mathrm{O}_{3}$, and (i) $\mathrm{Pd}(0.18)-$ $\mathrm{Bi}(0.4) / \mathrm{Ga}_{2} \mathrm{O}_{3}$. Red and blue solid bars represent the production rates of ethane and hydrogen, respectively. Black solid line with markers represents the ratio of production rates of ethane and hydrogen, $R\left(\mathrm{C}_{2} \mathrm{H}_{6} / \mathrm{H}_{2}\right)$, while the black dashed line represents the ideal ratio $R\left(\mathrm{C}_{2} \mathrm{H}_{6} / \mathrm{H}_{2}\right)=1$. Reaction conditions were the same as those described in the footnote $a$ of Table 1. 
Fig. S4 shows the optimization of the total loading amount of $\mathrm{Pd}-\mathrm{Bi}$ in the $\mathrm{Pd}(x)$ $\mathrm{Bi}(y) / \mathrm{Ga}_{2} \mathrm{O}_{3}$ samples.

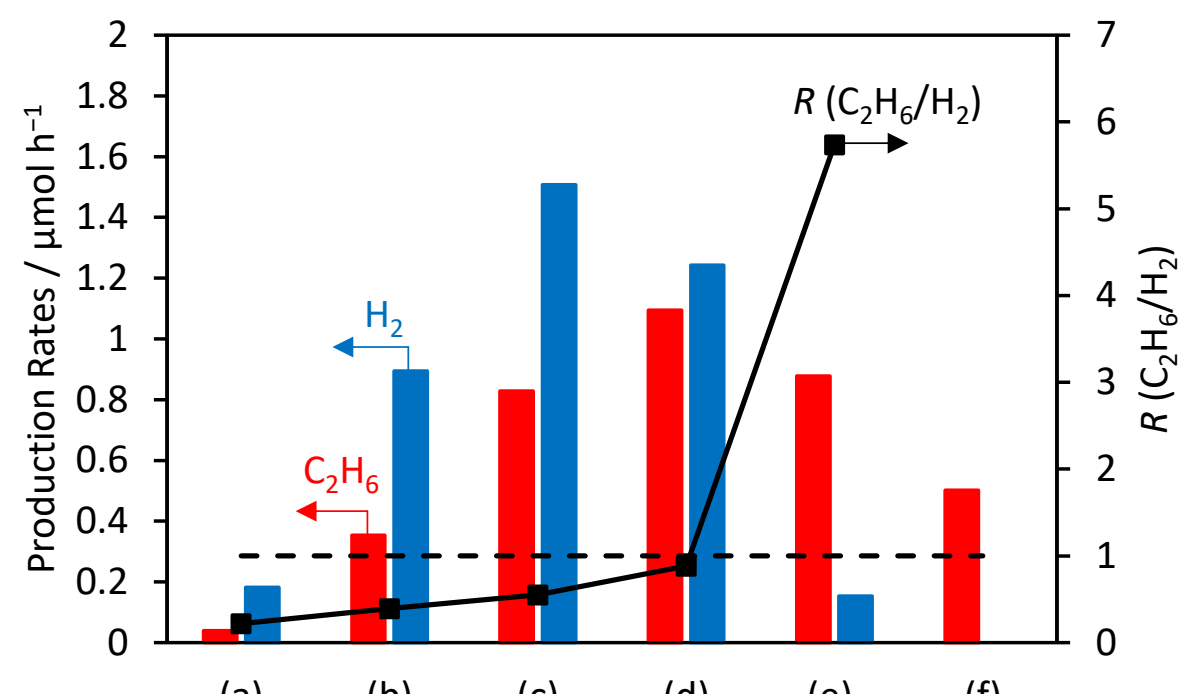

(a)

(b)

(c)

(d)

(e)

(f)

Fig. S4. Results of the NOCM reaction tests over the samples, (a) bare $\mathrm{Ga}_{2} \mathrm{O}_{3}$, (b) $\mathrm{Pd}(0.18) / \mathrm{Ga}_{2} \mathrm{O}_{3}$, (c) $\mathrm{Pd}(0.09)-\mathrm{Bi}(0.025) / \mathrm{Ga}_{2} \mathrm{O}_{3}$, (d) $\mathrm{Pd}(0.18)-\mathrm{Bi}(0.05) / \mathrm{Ga}_{2} \mathrm{O}_{3}$, (e) $\mathrm{Pd}(0.36)-\mathrm{Bi}(0.1) / \mathrm{Ga}_{2} \mathrm{O}_{3}$, and (f) $\mathrm{Pd}(0.54)-\mathrm{Bi}(0.15) / \mathrm{Ga}_{2} \mathrm{O}_{3}$. Red and blue solid bars represent the production rates of ethane and hydrogen, respectively. Black solid line with markers represents the ratio of production rates of ethane and hydrogen, $R\left(\mathrm{C}_{2} \mathrm{H}_{6} / \mathrm{H}_{2}\right)$, while the black dashed line represents the ideal ratio $R\left(\mathrm{C}_{2} \mathrm{H}_{6} / \mathrm{H}_{2}\right)=1$. Reaction conditions were the same as those described in the footnote $a$ of Table 1 . 


\subsection{Effect of Thermal Energy}

We examined whether the thermal energy provided at high temperatures can drive the NOCM reaction over the $\mathrm{Pd}(0.18)-\mathrm{Bi}(0.05) / \mathrm{Ga}_{2} \mathrm{O}_{3}$ sample under the dark condition. These results indicated that the NOCM did not proceed and the MD took place at high temperatures instead of the desired NOCM (Table S3).

Table S3. Results of reaction tests of the NOCM over the $\mathrm{Pd}(0.18)-\mathrm{Bi}(0.05) / \mathrm{Ga}_{2} \mathrm{O}_{3}$ sample at different temperatures in the dark $^{a}$

\begin{tabular}{ccccc}
\hline Entry & Temperature / $\mathrm{K}$ & \multicolumn{2}{c}{ Production Rates $/ \mu \mathrm{mol} \mathrm{h}{ }^{-1}$} & $R\left(\mathrm{C}_{2} \mathrm{H}_{6} / \mathrm{H}_{2}\right)^{b}$ \\
\cline { 3 - 4 } & & $\mathrm{C}_{2} \mathrm{H}_{6}$ & $\mathrm{H}_{2}$ & \\
\hline 1 & 323 & n.d. ${ }^{c}$ & n.d. ${ }^{c}$ & $-{ }^{d}$ \\
2 & 373 & n.d. ${ }^{c}$ & n.d. ${ }^{c}$ & $-{ }^{d}$ \\
3 & 473 & n.d. ${ }^{c}$ & n.d. & $-{ }^{d}$ \\
4 & 573 & n.d. ${ }^{c}$ & 0.38 & 0.0 \\
\hline
\end{tabular}

${ }^{a}$ The production rates were measured after $1.5 \mathrm{~h}$ from the start of the photoirradiation. Other reaction conditions were the same as those described in the footnote $a$ of Table 1. ${ }^{b}$ Calculated as follows: $R\left(\mathrm{C}_{2} \mathrm{H}_{6} / \mathrm{H}_{2}\right)=$ (production rate of ethane)/(production rate of hydrogen). ${ }^{c}$ n.d.: not detected. ${ }^{d}$ The $R\left(\mathrm{C}_{2} \mathrm{H}_{6} / \mathrm{H}_{2}\right)$ value could not be calculated.

The color of the $\mathrm{Pd}(0.18)-\mathrm{Bi}(0.05) / \mathrm{Ga}_{2} \mathrm{O}_{3}$ sample changed after the reaction test at $573 \mathrm{~K}$ in the dark (Fig. S5). This color change was probably due to coke formation.

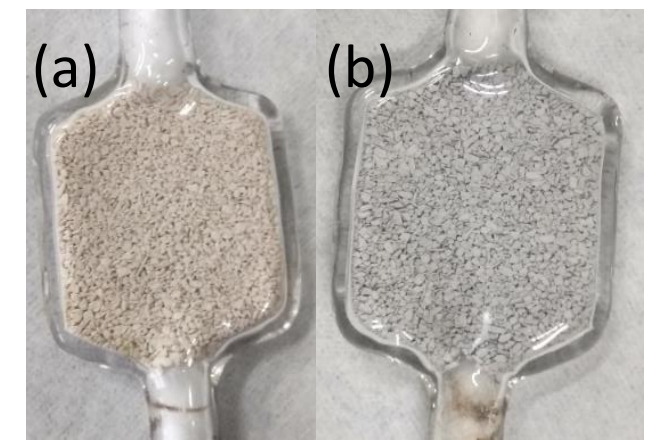

Fig. S5. Photographs of the sample cell with the $\mathrm{Pd}(0.18)-\mathrm{Bi}(0.05) / \mathrm{Ga}_{2} \mathrm{O}_{3}$ sample, (a) before the reaction test and (b) after the reaction test at $573 \mathrm{~K}$ in the dark. The size of the quartz reactor cell was $2 \times 2 \times 0.1 \mathrm{~cm}^{3}$. The photographs were taken by S. P. Singh. 


\subsection{Recyclability Test}

We tested the recyclability of the $\mathrm{Pd}(0.18)-\mathrm{Bi}(0.18) / \mathrm{Ga}_{2} \mathrm{O}_{3}$ sample for the reaction test and the results are shown in Fig S6. No significant decrease in the activity and the selectivity was observed after the three cycles.

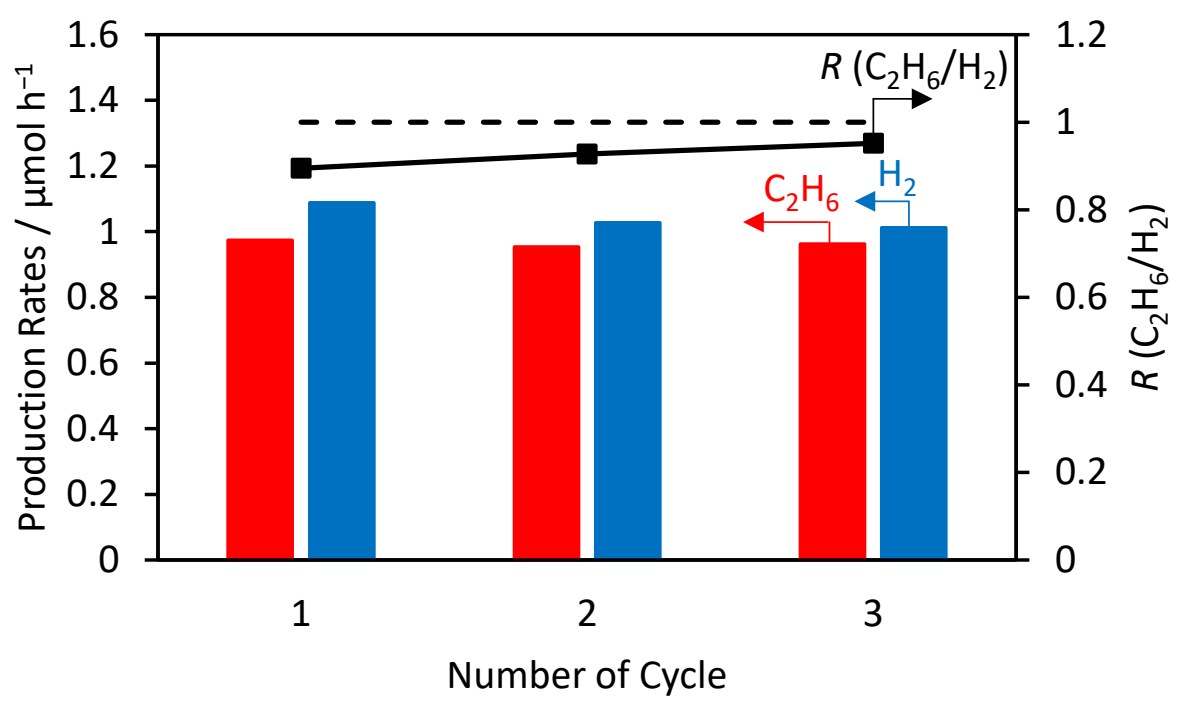

Fig. S6. Results of recycle test over the $\mathrm{Pd}(0.18)-\mathrm{Bi}(0.18) / \mathrm{Ga}_{2} \mathrm{O}_{3}$ sample. The sample was collected after the one cycle of the NOCM reaction test and then used for the next cycle as it was without any treatment. Red and blue solid bars represent the production rates of ethane and hydrogen, respectively. Black solid line with markers represents the ratio of production rates of ethane and hydrogen, $R\left(\mathrm{C}_{2} \mathrm{H}_{6} / \mathrm{H}_{2}\right)$, while the black dashed line represents the ideal ratio, $R\left(\mathrm{C}_{2} \mathrm{H}_{6} / \mathrm{H}_{2}\right)=1$. The other reaction conditions were the same as those described in the footnote $a$ of Table 1. 


\subsection{Color Change in $\mathrm{TiO}_{2}$ after the Reaction}

Fig. S7 shows the photographs of a sample cell before and after a reaction test with the bare $\mathrm{TiO}_{2}$ (ST-01) sample. The color of the $\mathrm{TiO}_{2}$ sample on the irradiated side varied from white to blue during the photocatalytic reaction test, indicating the sample was reduced under the reaction conditions. But the blue color at the upper side in the cell became white immediately on exposing to the air when the cell was took off from the reaction system (Fig. S7b).

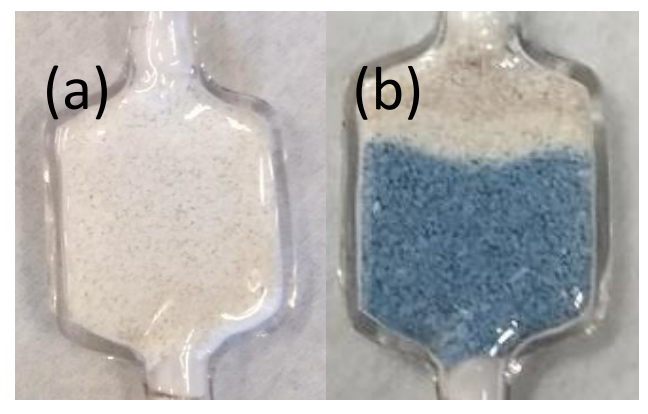

Fig. S7. The photograph of the sample cell (a) before and (b) after the reaction test of the NOCM over the bare $\mathrm{TiO}_{2}$ (ST-01) sample. The photographs were taken by S. P. Singh.

\subsection{BET Specific Surface Areas of the Samples}

The BET specific surface areas (SSA) of the various samples are listed in the Table S4.

Table S4 BET specific surface areas (SSA) of the samples

\begin{tabular}{ccc}
\hline Entry & Samples & $\mathrm{SSA}_{\mathrm{avg}}\left(\mathrm{m}^{2} \mathrm{~g}^{-1}\right)^{a}$ \\
\hline 1 & $\mathrm{Ga}_{2} \mathrm{O}_{3}$ & $14.4( \pm 0.3)$ \\
2 & $\mathrm{Bi}(0.18) / \mathrm{Ga}_{2} \mathrm{O}_{3}$ & $16.9( \pm 0.1)$ \\
3 & $\mathrm{Pd}(0.18) / \mathrm{Ga}_{2} \mathrm{O}_{3}$ & $17.6( \pm 0.2)$ \\
4 & $\mathrm{Pd}(0.18)-\mathrm{Bi}(0.18) / \mathrm{Ga}_{2} \mathrm{O}_{3}$ & $16.5( \pm 0.2)$ \\
5 & $\mathrm{Pd}(0.18)-\mathrm{Bi}(0.05) / \mathrm{Ga}_{2} \mathrm{O}_{3}$ & $15.7( \pm 0.2)$ \\
\hline
\end{tabular}

${ }^{a}$ The value in parenthesis is a standard deviation calculated from multiple measurements. 


\subsection{TEM Images}

TEM images of the samples are shown in Fig. S8. Some nanoparticles could be detected after loading of Pd (Fig. S8 b), Bi (Fig. S8 c), and Pd-Bi (Fig. S8 d) cocatalysts on $\mathrm{Ga}_{2} \mathrm{O}_{3}$.
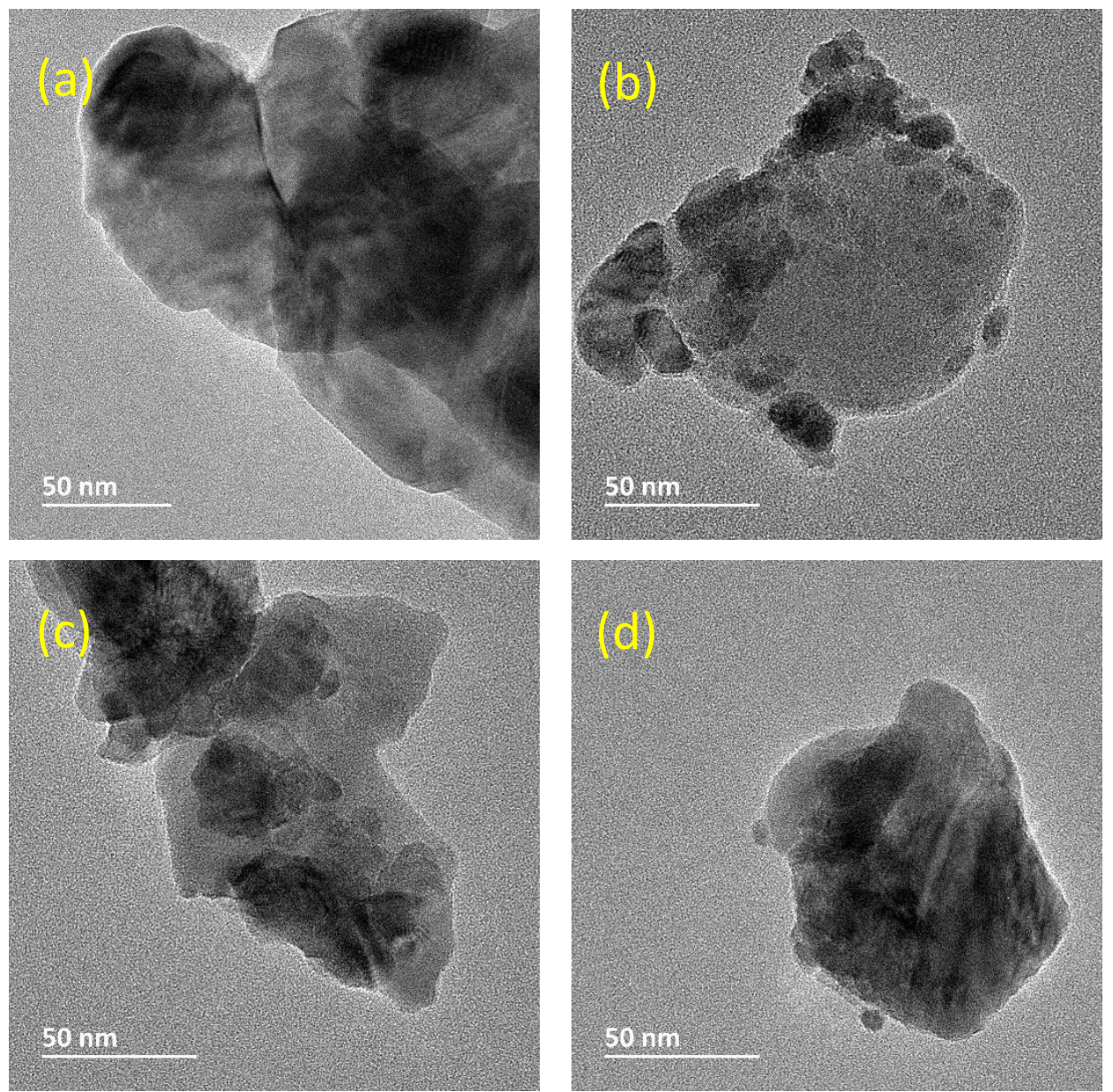

Fig. S8. TEM images of the samples, (a) bare $\mathrm{Ga}_{2} \mathrm{O}_{3}$, (b) $\mathrm{Pd}(0.18) / \mathrm{Ga}_{2} \mathrm{O}_{3}$, (c) $\mathrm{Bi}(0.18) / \mathrm{Ga}_{2} \mathrm{O}_{3}$, and (d) $\mathrm{Pd}(0.18)-\mathrm{Bi}(0.05) / \mathrm{Ga}_{2} \mathrm{O}_{3}$. 


\subsection{Photographs of the Irradiated and Non-irradiated Side of the Sample Cell}

The photographs of the sample cell before the reaction test, after the reaction test on the irradiated front side and after the reaction test on the non-irradiated back side with the $\mathrm{Pd}(3.6)-\mathrm{Bi}(1) / \mathrm{Ga}_{2} \mathrm{O}_{3}$ sample are shown below.
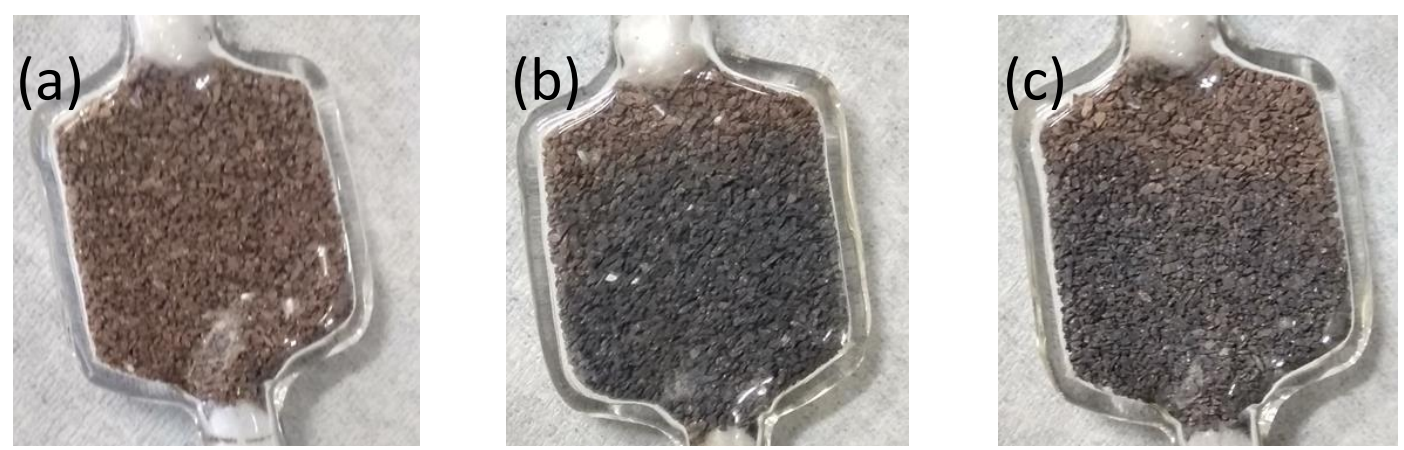

Fig. S9. Photographs of the sample cell with the $\mathrm{Pd}(3.6)-\mathrm{Bi}(1) / \mathrm{Ga}_{2} \mathrm{O}_{3}$ sample for the photocatalytic NOCM reaction test; (a) before the reaction test, (b) the irradiated side after the reaction test, (c) the back side after the reaction test. The photographs were taken by S. P. Singh.

The color change is due to the reduction of $\mathrm{PdO}$ species to metallic $\mathrm{Pd}$ on the $\mathrm{Ga}_{2} \mathrm{O}_{3}$ particles during the reaction test of the NOCM. As is evident from the photographs, the irradiated side became much darker after the reaction test while the back non-irradiated side was less dark. 


\subsection{Reaction Test over the Reduced $\mathrm{Pd}-\mathrm{Bi} / \mathrm{Ga}_{2} \mathrm{O}_{3}$ Sample}

We pretreated the $\mathrm{Pd}(0.18)-\mathrm{Bi}(0.18) / \mathrm{Ga}_{2} \mathrm{O}_{3}$ sample under a flow of $\mathrm{H}_{2}$ at $673 \mathrm{~K}$ for $0.5 \mathrm{~h}$ and represented it as the $r-\mathrm{Pd}(0.18)-\mathrm{Bi}(0.18) / \mathrm{Ga}_{2} \mathrm{O}_{3}$ sample. The $r-\mathrm{Pd}(0.18)-\mathrm{Bi}(0.18) / \mathrm{Ga}_{2} \mathrm{O}_{3}$ sample exhibited two times higher activity than the $\mathrm{Pd}(0.18)-\mathrm{Bi}(0.18) / \mathrm{Ga}_{2} \mathrm{O}_{3}$ sample with nearly unchanged selectivity (Fig. S10).

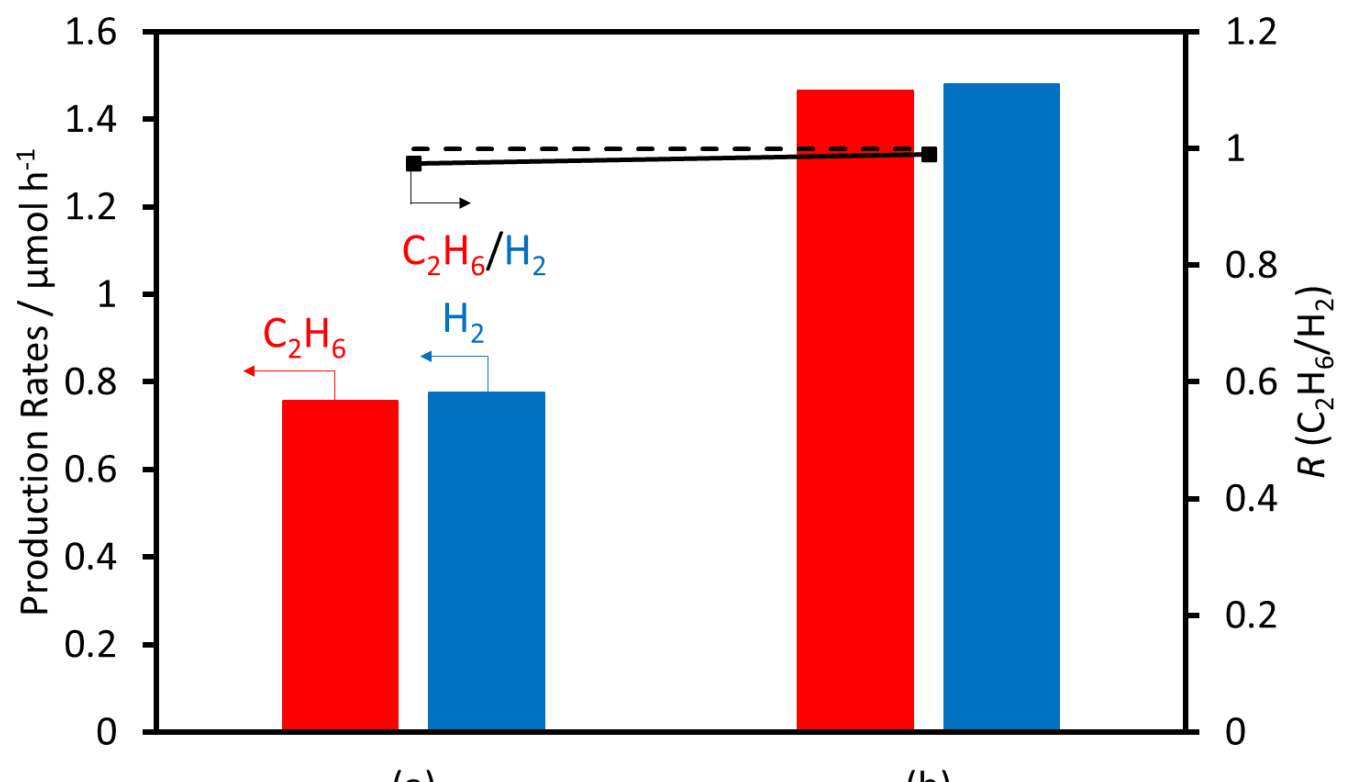

(a)

(b)

Fig. S10: Results of reaction tests for the NOCM over the samples, (a) $\mathrm{Pd}(0.18)$ $\mathrm{Bi}(0.18) / \mathrm{Ga}_{2} \mathrm{O}_{3}$ and (b) $r-\mathrm{Pd}(0.18)-\mathrm{Bi}(0.18) / \mathrm{Ga}_{2} \mathrm{O}_{3}$. Red and blue solid bars represent the production rates of ethane and hydrogen, respectively. Black solid line with markers represents the ratio of production rates of ethane and hydrogen, $R\left(\mathrm{C}_{2} \mathrm{H}_{6} / \mathrm{H}_{2}\right)$, while the black dashed line represents the ideal ratio, $R\left(\mathrm{C}_{2} \mathrm{H}_{6} / \mathrm{H}_{2}\right)=1$. The other reaction conditions were the same as those described in the footnote $a$ of Table 1. 


\subsection{Reaction Test over the $\mathrm{Pd}-\mathrm{Bi} / \mathrm{Ga}_{2} \mathrm{O}_{3}$ Sample with a Filter $(\lambda \geq 330 \mathrm{~nm})$}

We applied a UV cut-off filter $\left(\lambda_{\text {transmission }} \geq 330 \mathrm{~nm}\right)$ and did the reaction test of the NOCM over the $\mathrm{Pd}(0.18)-\mathrm{Bi}(0.18) / \mathrm{Ga}_{2} \mathrm{O}_{3}$ sample. A very small amount of ethane and no hydrogen were observed after $5.5 \mathrm{~h}$ photoirradiation (Table S5, Entry 2).

Table S5. The results of reaction test of the NOCM over the $\mathrm{Pd}(0.18)-\mathrm{Bi}(0.18) / \mathrm{Ga}_{2} \mathrm{O}_{3}$ sample without and with the filter ${ }^{a}$

\begin{tabular}{ccccc}
\hline \multirow{2}{*}{ Entry } & Conditions & \multicolumn{2}{c}{ Production Rates $/ \mu \mathrm{mol} \mathrm{h}{ }^{-1}$} & $R\left(\mathrm{C}_{2} \mathrm{H}_{6} / \mathrm{H}_{2}\right)^{b}$ \\
\cline { 2 - 4 } & & $\mathrm{C}_{2} \mathrm{H}_{6}$ & $\mathrm{H}_{2}$ & \\
\hline 1 & Without filter & 0.95 & 1.1 & 0.86 \\
2 & With filter $\left(\lambda_{\text {transmission }} \geq 330 \mathrm{~nm}\right)$ & 0.04 & n.d. ${ }^{c}$ & $-{ }^{d}$ \\
\hline
\end{tabular}

${ }^{a}$ Reaction conditions were the same as those described in the footnote $a$ of Table $1 .{ }^{b}$ Calculated as follows: $R\left(\mathrm{C}_{2} \mathrm{H}_{6} / \mathrm{H}_{2}\right)=$ (production rate of ethane)/(production rate of hydrogen). ${ }^{c}$ n.d.: not detected. ${ }^{d}$ The $R\left(\mathrm{C}_{2} \mathrm{H}_{6} / \mathrm{H}_{2}\right)$ value could not be calculated. 
2.10. DR UV-vis Spectra of the $\mathrm{Bi}_{2} \mathrm{O}_{3}$ and $\mathrm{Pd}(0.18) / \mathrm{Bi}_{2} \mathrm{O}_{3}$ Samples

Fig. S11 shows the DR UV-vis spectra of the $\mathrm{Bi}_{2} \mathrm{O}_{3}$ sample (black line) and the $\mathrm{Pd}(0.18) / \mathrm{Bi}_{2} \mathrm{O}_{3}$ sample (blue line).

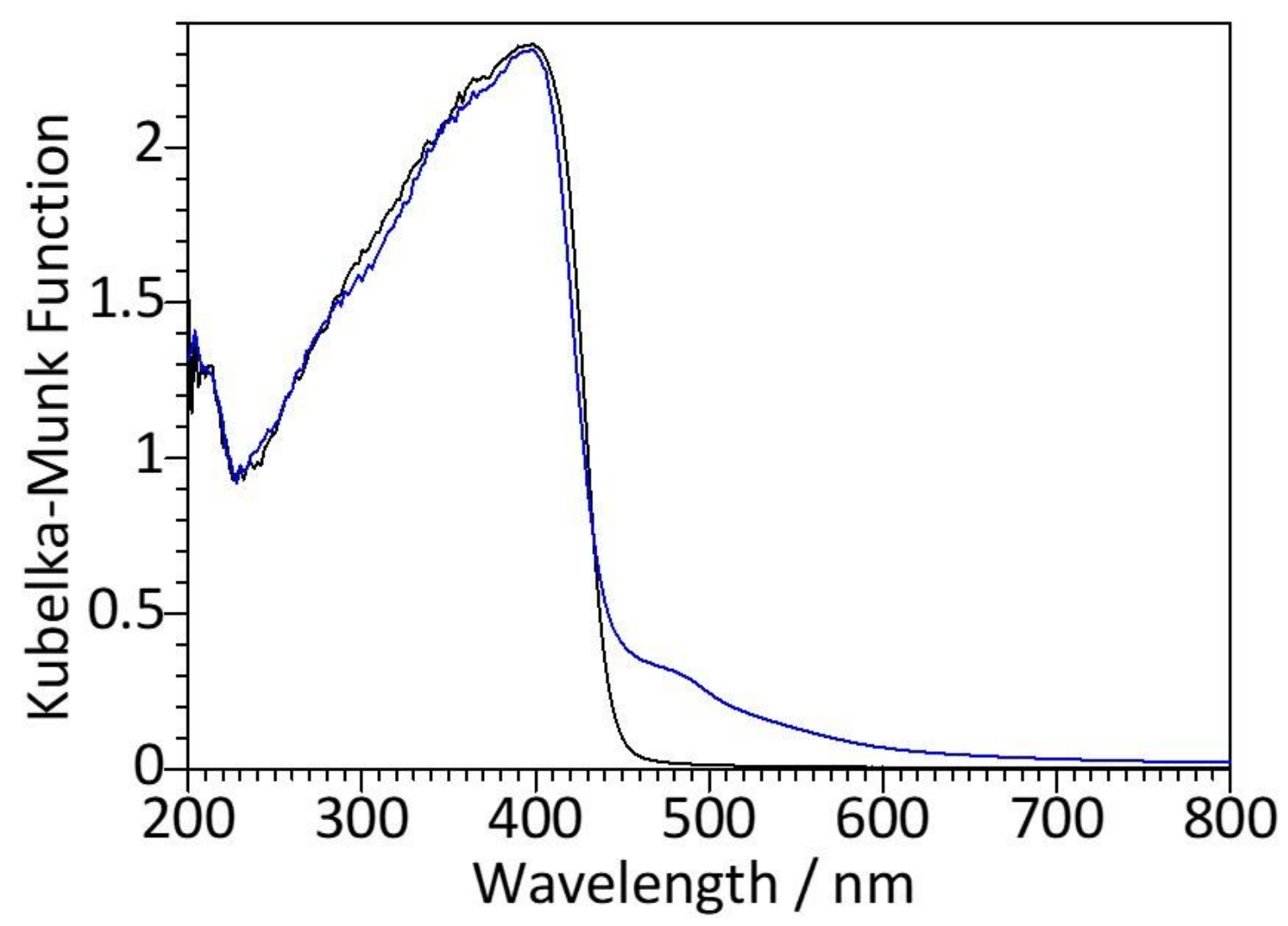

Fig. S11. DR UV-vis spectra of the $\mathrm{Bi}_{2} \mathrm{O}_{3}$ (black line) and $\mathrm{Pd}(0.18) / \mathrm{Bi}_{2} \mathrm{O}_{3}$ (blue line) samples. 


\subsection{Reaction Test over the $\mathrm{Bare} \mathrm{Bi}_{2} \mathrm{O}_{3}$ Sample and the $\mathrm{Pd} / \mathrm{Bi}_{2} \mathrm{O}_{3}$ Sample}

We did the reaction test of the NOCM over the bare $\mathrm{Bi}_{2} \mathrm{O}_{3}$ sample and the $\mathrm{Pd} / \mathrm{Bi}_{2} \mathrm{O}_{3}$ sample and results are listed in Table S6. No products were detected after $5.5 \mathrm{~h}$ of photoirradiation.

Table S6. Results of reaction tests of the NOCM over the $\mathrm{Bi}_{2} \mathrm{O}_{3}$ and the $\mathrm{Pd}(0.18) / \mathrm{Bi}_{2} \mathrm{O}_{3}$ samples ${ }^{a}$

\begin{tabular}{cccc}
\hline Entry & Sample & \multicolumn{2}{c}{ Production Rates / $\mu \mathrm{mol} \mathrm{h}^{-1}$} \\
\cline { 3 - 4 } & & $\mathrm{C}_{2} \mathrm{H}_{6}$ & $\mathrm{H}_{2}$ \\
\hline 1. & $\mathrm{Bi}_{2} \mathrm{O}_{3}$ & n.d. ${ }^{b}$ & n.d. ${ }^{b}$ \\
2. & $\mathrm{Pd}(0.18) / \mathrm{Bi}_{2} \mathrm{O}_{3}$ & n.d. ${ }^{b}$ & n.d. ${ }^{b}$ \\
\hline
\end{tabular}

${ }^{a}$ Reaction conditions were the same as those described in the footnote $a$ of Table 1 . The loading amount was in mol \%. ${ }^{b}$ n.d.: not detected. 


\subsection{Effect of Irradiation Area on the Photocatalytic Activity}

In order to study the effect of irradiation area on the photocatalytic activities, we reduced the irradiation area for the $\mathrm{Pd} / \mathrm{Ga}_{2} \mathrm{O}_{3}$ sample and the $\mathrm{Bi} / \mathrm{Ga}_{2} \mathrm{O}_{3}$ sample to nearly half by filling a half of the sample cell with quartz sand and another half with photocatalyst in each case (total weight of the quartz sand and catalyst was $0.8 \mathrm{~g}$ ) and represented these samples as $P d+Q$ and $Q+B i$, respectively, for simplicity. The results of reaction tests of the NOCM over the $\mathrm{Pd} / \mathrm{Ga}_{2} \mathrm{O}_{3}$ sample, the $\mathrm{Pd}+\mathrm{Q}$ sample, the $\mathrm{Pd}+\mathrm{Q}+\mathrm{Bi}$ sample, the $\mathrm{Q}+\mathrm{Bi}$ sample and the $\mathrm{Bi} / \mathrm{Ga}_{2} \mathrm{O}_{3}$ sample and the photographs of the sample cells are shown in Fig. S12.

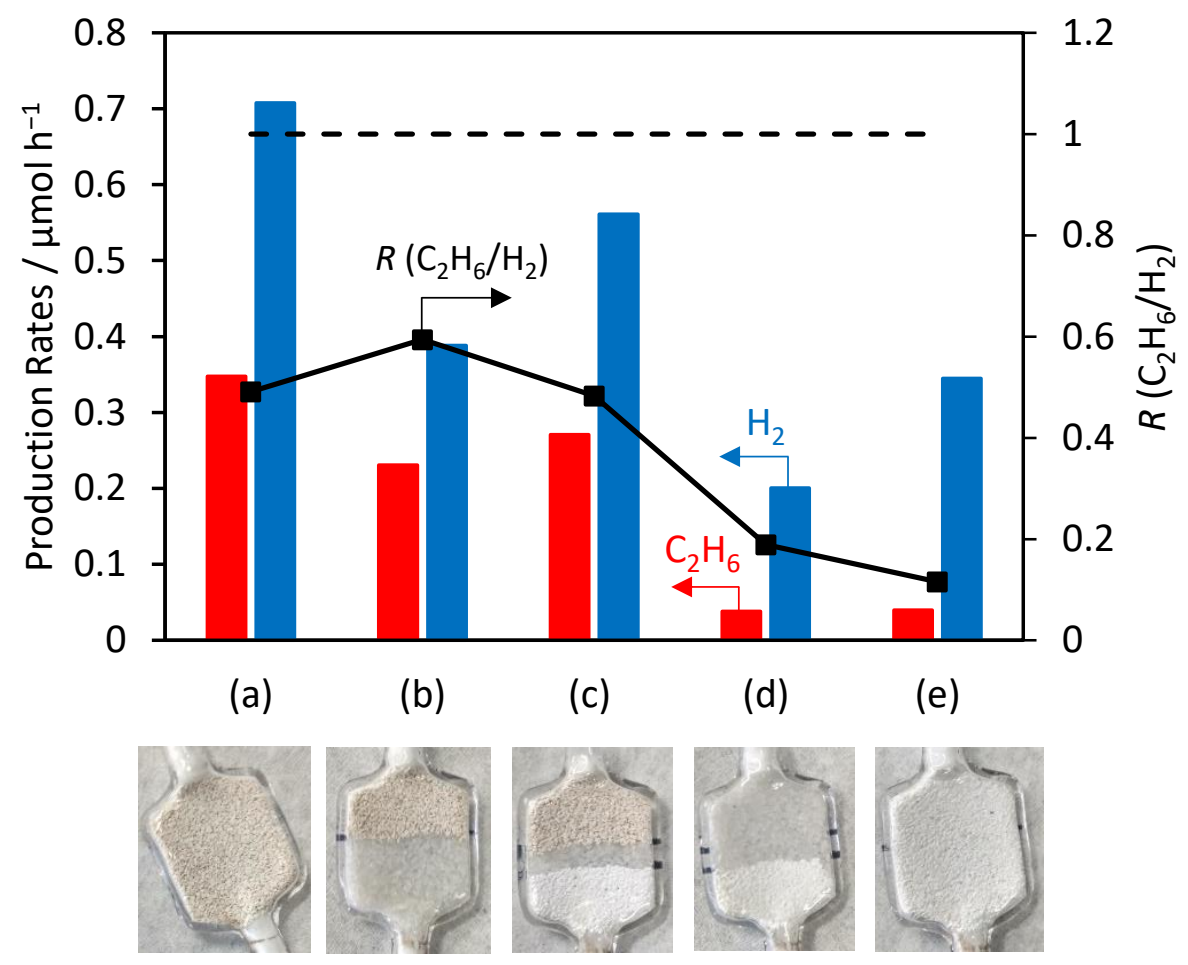

Fig. S12. The results of reaction tests over the samples, (a) $P d(0.18) / G_{2} O_{3}$, (b) $P d+Q$, (c) $P d+Q+B i$, (d) $\mathrm{Q}+\mathrm{Bi}$, and (e) $\mathrm{Bi}(0.18) / \mathrm{Ga}_{2} \mathrm{O}_{3}$ and the photographs of their respective sample cells. Red and blue solid bars represent the production rates of ethane and hydrogen, respectively. Black solid line with markers represents the ratio of production rates of ethane and hydrogen, $R\left(\mathrm{C}_{2} \mathrm{H}_{6} / \mathrm{H}_{2}\right)$, while the black dashed line represents the ideal ratio $R\left(\mathrm{C}_{2} \mathrm{H}_{6} / \mathrm{H}_{2}\right)=1$. Reaction conditions were same as those described in the footnote $a$ Table 1 . The photographs of the sample cells were taken by S. P. Singh. 


\subsection{Integration Manner of $\mathrm{Pd} / \mathrm{Ga}_{2} \mathrm{O}_{3}$ and $\mathrm{Bi} / \mathrm{Ga}_{2} \mathrm{O}_{3}$ Samples}

In order to vary the spatial distance between the Bi species and the Pd species, the $\mathrm{Pd} / \mathrm{Ga}_{2} \mathrm{O}_{3}$ and $\mathrm{Bi} / \mathrm{Ga}_{2} \mathrm{O}_{3}$ photocatalysts were arranged in the sample cell in different integration manner (Fig. S13).

(a)

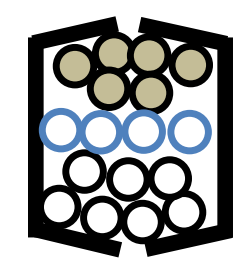

(b)

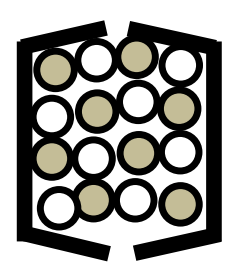

(c)

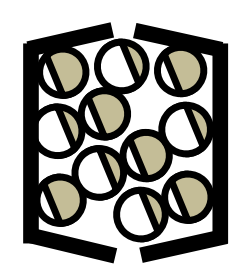

Fig. S13. The integration manner in samples (a) $P d+Q+B i,(b) L C M$, and (c) TCM. The circles represent granules of the photocatalyst samples and particles of the quartz sand.

\subsection{Time Course of the NOCM over the LCM Sample}

Both ethane and hydrogen were produced continuously for at least $30 \mathrm{~h}$ over the LCM sample (Fig. S14) consisting of granules mixture with Pd and Bi species located on different $\mathrm{Ga}_{2} \mathrm{O}_{3}$ particles suggesting the possibility of interparticle transfer of methyl radicals and electrons.

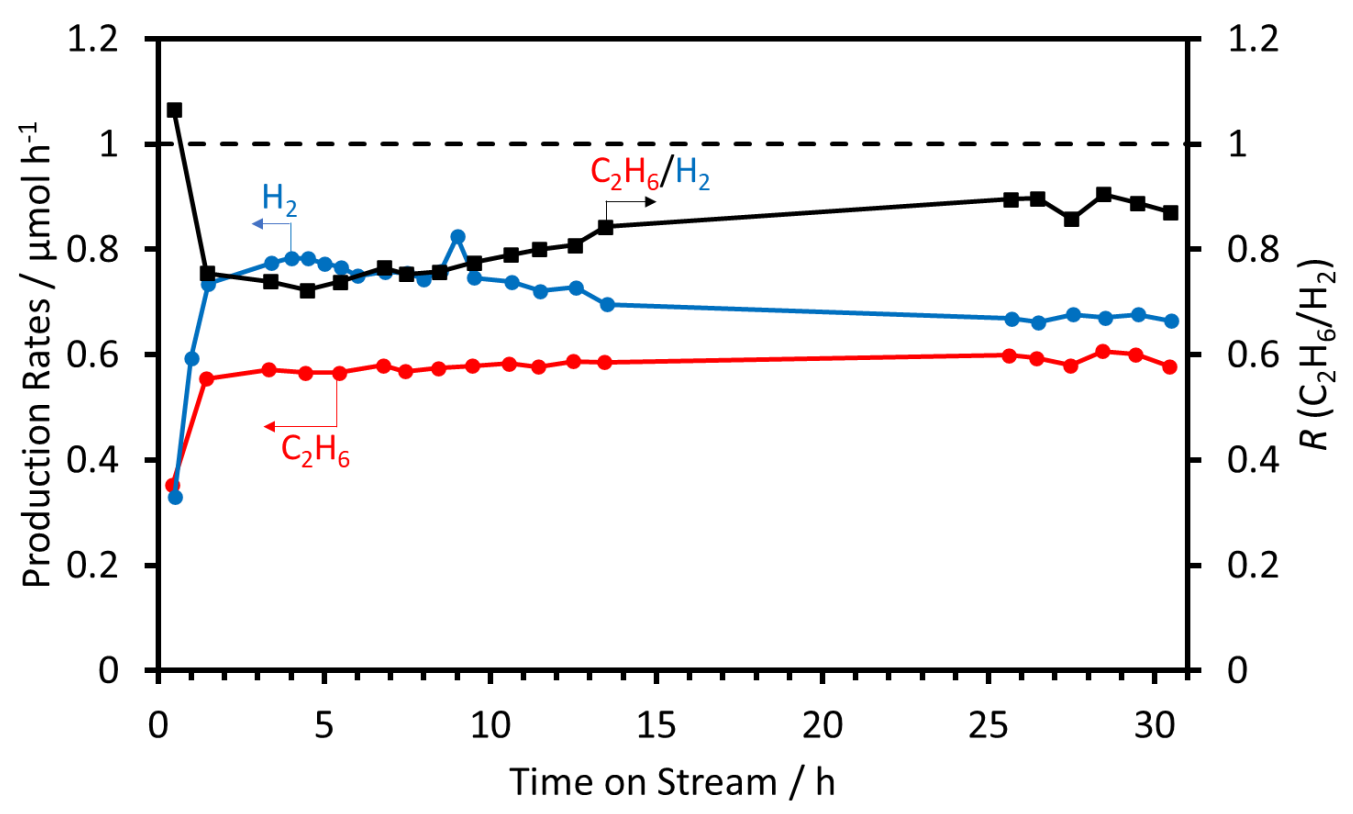

Fig. S14. Time course of the NOCM over the LCM sample. Reaction conditions were same as those described in the footnote $a$ of Table 1. 


\subsection{Relationship between the Production Rates and the $R$ value}

The relationships between the production rates and the $R$ value are shown in Fig. S15 A and S15 B for ethane and hydrogen production, respectively.
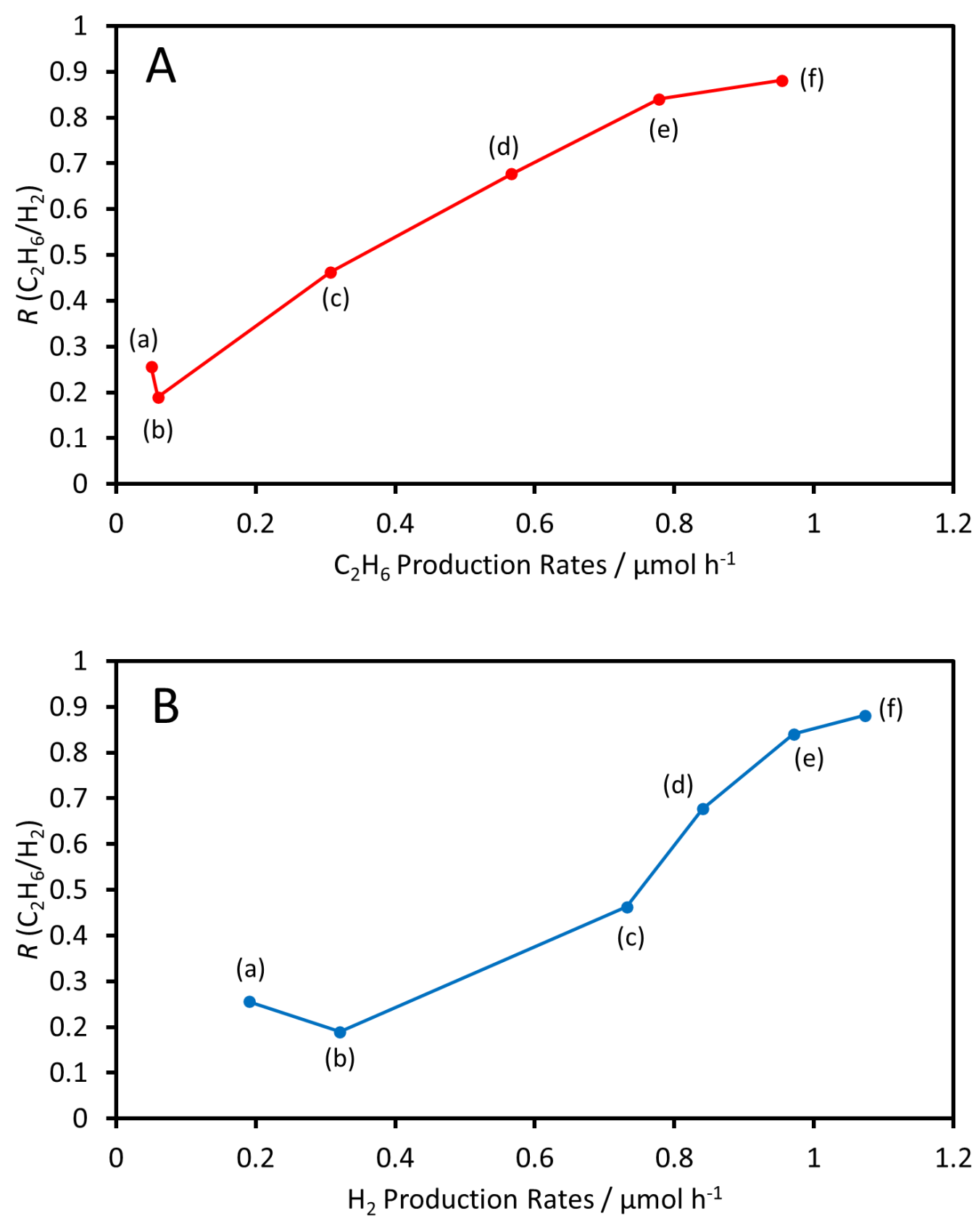

Fig. S15. The relationship between (A) the $R$ value and the ethane production rates and (B) the $R$ value and the hydrogen production rates over the samples. The data were obtained with the samples, (a) $\mathrm{Ga}_{2} \mathrm{O}_{3}$, (b) $\mathrm{Bi}(0.18) / \mathrm{Ga}_{2} \mathrm{O}_{3}$, (c) $\mathrm{Pd}(0.18) / \mathrm{Ga}_{2} \mathrm{O}_{3}$, (d) LCM, (e) TCM, and (f) $\mathrm{Pd}(0.18)-\mathrm{Bi}(0.18) / \mathrm{Ga}_{2} \mathrm{O}_{3}$.

With an increase in the activity of the photocatalyst, the value of $R$ is also increased suggesting that the selectivity for the NOCM is also increased in a similar manner. 


\section{REFERENCES}

(1) Yoshida, H.; Kato, S.; Hirao, K.; Nishimoto, J.-I.; Hattori, T. Photocatalytic Steam Reforming of Methane over Platinum-Loaded Semiconductors for Hydrogen Production. Chem. Lett. 2007, 36 (3), 430-431. https://doi.org/10.1246/cl.2007.430.

(2) Yoshida, H.; Hirao, K.; Nishimoto, J.-I.; Shimura, K.; Kato, S.; Itoh, H.; Hattori, T. Hydrogen Production from Methane and Water on Platinum Loaded Titanium Oxide Photocatalysts. J. Phys. Chem. C 2008, 112 (14), 5542-5551. https://doi.org/10.1021/jp077314u.

(3) Shimura, K.; Kato, S.; Yoshida, T.; Itoh, H.; Hattori, T.; Yoshida, H. Photocatalytic Steam Reforming of Methane over Sodium Tantalate. J. Phys. Chem. C 2010, 114 (8), 3493-3503. https://doi.org/10.1021/jp902761x.

(4) Yamamoto, A.; Mizuba, S.; Saeki, Y.; Yoshida, H. Platinum Loaded Sodium Tantalate Photocatalysts Prepared by a Flux Method for Photocatalytic Steam Reforming of Methane. Appl. Catal. A Gen. 2016, 521, 125-132. https://doi.org/10.1016/j.apcata.2015.10.031.

(5) Singh, S. P.; Anzai, A.; Kawaharasaki, S.; Yamamoto, A.; Yoshida, H. Non-Oxidative Coupling of Methane over Pd-Loaded Gallium Oxide Photocatalysts in a Flow Reactor. Catal. Today 2021, 375, 264-272. https://doi.org/10.1016/j.cattod.2020.04.023.

(6) Ishimaru, M.; Amano, F.; Akamoto, C.; Yamazoe, S. Methane Coupling and Hydrogen Evolution Induced by Palladium-Loaded Gallium Oxide Photocatalysts in the Presence of Water Vapor. J. Catal. 2021, 397, 192-200. https://doi.org/10.1016/j.jcat.2021.03.024. 